\title{
Photograph, Information Search and Tourism Marketing
}

\author{
Banafsheh M. Farahani (Corresponding author) \\ School of Housing Building and Planning, Universiti Sains Malaysia \\ 11800 Minden Penang, Malaysia \\ Tel: 60-17-446-7620 E-mail: banafsheh.farahani@gmail.com \\ Badaruddin Mohamed \\ School of Housing, Building \& Planning, Universiti Sains Malaysia \\ 11800 Minden Penang, Malaysia \\ Tel: 60-19-443-1894Ｅ-mail: bada@usm.my \\ Ahmad Puad Mat Som \\ School of Housing, Building \& Planning, Universiti Sains Malaysia \\ 11800 Minden Penang, Malaysia \\ Tel: 60-12-784-3358_E-mail: puad@usm.my
}

Received: October 20, $2010 \quad$ Accepted: March 7, $2011 \quad$ doi:10.5539/ass.v7n7p94

\begin{abstract}
In the age of globalization, being aware of tourist information search behavior is a fundamental factor for marketing management to decide and provide an effective marketing and service to their potential travelers. As information search is a first step in travel decision making therefore, marketers can provide proper information and influence travelers to make decision. Understanding Pre-purchase information search behavior has been an important concern for researchers on both theoretical and applied ground since early nineteen century till present. The provided information can be text based, image based (photograph) and voice based. The overall purpose of this paper is to better understanding of tourist data preference while searching for information. It explains how important and useful photograph can be in tourism information search and marketing in general. It is also shows the power of photograph to show the place characters. The data was collected from 204 tourists all over the world as well as related available secondary sources. The result of the study can be useful for tourism marketers to provide information related to tourists needs and desire.
\end{abstract}

Keywords: Information search behavior, Decision making, Internal information, External information, Photograph

\section{Introduction}

Having taken the importance of information search in travel decision making, potential travelers need to search for the information regarding to the destination they are willing to travel and the available services in the preferred destination. The information sources are divided into two categories known as internal source and external source. In internal source, the travelers search for the information through their long term memory which can be their previous trip to the same place or other similar places they have already visited, or even their earlier access to random information in the time they didn't want to travel. That information can be obtained from TV advertisement, billboards, books, magazines, newspaper or any other information sources. If those mentioned information was enough then travelers make their decision although, most of the time they need to search for more information from external sources. In today's dynamic global environment, understanding how travelers acquire information is necessary for marketing management decisions and designing effective marketing communication campaigns and service delivery (Gursoy and McCleary, 2004).

Definitely, understanding external information source use can help marketers efficiently tailor the promotional mix. Therefore, it is not surprising that consumer's information search has been one of the most studied subjects 
in consumer research (Schmidt and Spreng, 1996). Accordingly, marketing and consumer behavior researchers have been examining the consumer's pre-purchase information seeking behavior at least since 1917 (e.g., Copeland, 1917), and even today most consumer information processing and decision-making models include pre-purchase information search as one of the key components (e.g., Engel et al., 1995; Howard and Sheth, 1969). External information sources provide three types of information for potential travelers. They use text based, image based and voice based data. This study focuses on image based data (photograph) and tourist preference to receive data in this type of information. The study also shows the success of using photographs in different media as well as tourists media preference. Furthermore it shows the success of using photograph in different media as an instrument. In regards to the importance of decision making for marketing, this study shows how photograph helps tourists to make their decision. Moreover, it shows the percentage of showing reality by photograph. The last part is about the power of photograph in showing place characters.

\section{Internal and External Information Search}

Engel et.al (1995) defined information search as motivated activation of stored knowledge in memory or acquisitions of information from environment. When consumers find any kind of needs or problems, they will start to search their long term memory to find the available alternatives to satisfy their needs or solve the problems. This searching for information is internal information search which is retrieving decision-relevant information stored in individuals' long term memory (Crotts, 2000). If the internal search fulfills the consumer needs, there is no need to get to the next level; however, most of the time the information stored in long term memory is not enough therefore, the consumers start to search through external sources. This is called external information search (See Figure 1).

Okazaki, (2009) divided the external information sources in two groups as; marketing and non-marketing sources. He believes that the importance of the external information sources increase, when consumers move into complete decision making, like planning for a vacation. In external search, potential travelers are thought to acquire information from different information sources, which may be marketing or non-marketing ones.

On the other hand, Crotts, (2000) by analyzing Beatty and Smith, 1987; Assael, 1987; Hawkins, Best, and Coney, 1995 research divided the sources of external information into four basic categories; " (1) Personal (e.g., friends and relatives advice), (2) marketer- dominated (e.g., brochures, advertisements in print and electronic media), (3) neutral (e.g., travel club, travel guides, travel agents), and (4) experiential sources (e.g., inspections, pre-purchase visit, or store contract). Many consider internet as the fifth category but the others put it in market dominated or neutral sources depending on their purpose or content." (Crotts, 2000, p. 152)

\section{Photography and Tourism}

A photograph (often shorten to photo) is used in diverse purpose. Advertising, fashion, crime scene, still life, food, editorial photographs as well as photo journalism are different usage of photograph. Portrait and wedding, fine art and landscape photographs can be added to the list as well. Bell (1914) asserts that one picture is worth than a thousand words, in this matter magazine and newspaper, companies' websites, and advertising agencies pay for photography in order to gain their objectives. Jenkins (2003) presents another view of photography as the most common attribute of tourist behavior. He separated tourist photography in both photos taking by tourists and those which present to tourist by member of the host community. Urry (1990) presents the same view points as photography is a link to the notion of requirement connecting both tourists and tourism provider.

Although there is an argument that tourism predates photography (Lofgren, 1985) and photography intend discourse of tourism before photography was even invented by sketching and image hunting (Larsen, 2004), but in comprehensive view, tourism and photography are closely intertwined. Each of them shaping and stimulating the other. Lofgren (1985) claims that photography service tourism in advertisements commodity, instruction and memento while tourism serving photography as financial support, vehicle, justification and structuring activities. Accordingly, Human and Warren (1996) mention that photography and tourism have experienced surprising similar process of industrialization with common origin in 1841.

According to Geary and Webb (1998) photography promote tourism in different media as newspaper and magazine advertisement, brochures, billboards, railway station, websites and television commercials. They are appeared in feature stories, informational travelogues, coffee table, book and museum exhibition with the same purpose. In addition Sontag (1979) noted that photography can make the invisible visible, the unnoticed noticed, complex simple and simple complex. Those powers of photography help to convey the message to the viewers efficiently and make photograph the best tool in tourism marketing. It is also confirmed by Taylor (1984) and Osborne (2000) that photography has been a big help in tourism development. 
Sontag (1977) refers to photograph as a tool to motivate individual tourist to travel. Dann (1995) had the same idea that tourist behavior as well as their motivation can be controlled and determined by photography. Moreover, Gernsheim (1991) believes that photograph is the only language understood in all parts of the world. Additionally Urray (1990) said that photographic images organize individuals' expectation or day dreaming about the place people might visit. In order to confirm Urray's idea, Tonkonow (1995) refers to imagination of going to the place which the picture is seen by potential travelers.

Haywood (1990) asserts that modern tourism is dependent on photographic images which form tourism brochures and other marketing tools. Albers and James (1998) also mentioned that tourists like to visit the place which they saw the picture in brouchures and surprisingly they like to take the same picture which they saw in leaflets before visiting the place. Dann (1995) as another researcher refers to iconic attractions of a country. The tourist number increase in the condition of positive iconic attractions and decrease in the case of negative iconic attractions. He points out that using an inappropriate icon may act as negative marketing tool. Benjamin (1979) also claims that the projection of an appropriate destination image is widely accepted as a vital element in tourism marketing and to be a critical factor in travelers' decisions. It is important to note that research shows, as a result of visiting the destination, the images tourists hold of the places they have seen tend to be more realistic, complex and differentiated (chon, 1987). Chalfen (1987) has suggested that the photograph is often portrays the preferred image of the host society.

This study finds the influence of photograph in different media on tourist decision as well as their preferred media which contain photographs to get information from. It is also focuses on the presenting real picture of different attractions by photographs according to tourist perspectives. It also answers to the question whether photograph is able to show all place characters or not.

\section{Research Methodology}

In order to identify the role of photographs in tourism marketing and its influence in tourists' information search, the data was collected from the target populations of tourists either domestic or international regardless of their age, sex, marital status, their living area, nationality, education level and occupations. The resultant sample size of 200 was deemed adequate to support the statistical techniques employed. Simple random sampling was used to randomly choose tourists from five areas as: Asia, Europe, Africa, America and Middle East. A total of 298 respondents participated in this study but only 204 questionnaires were fully completed and used. The instruments for this research include a web-based survey and a conventional survey. The survey composed of 22 questions and its purpose was to obtain information in relation to tourists' information search behavior and their preference regarding image based data (photographs). The questionnaire was divided into two parts. In the first part, most of the questions were pre-coded with single choice answers and was about respondents' demographic profile. In the second part, five-point Likert scale was used to measure the respondent's predisposition toward certain actions and behavior. Respondents were asked to rate the different image base data according to their preference level and their importance in marketing sector.

\section{Research Findings}

The result of this study are grouped to six parts as the respondents preference of the type of data they receive during their information search, their preferred media for getting information from, important media in marketing, the importance of photographs in decision making, the extend in which photographs shows reality, photographs and destination choice and projecting the character of the place by using photographs.

\subsection{Information Preference}

Figure 2 shows that $27.5 \%$ of respondents, preferred textual data, while $55.6 \%$ of them preferred image based data and $17.2 \%$ of them liked to receive voice based data while they are searching for information. As photograph is the only language understood in all parts of the world (Gernsheim, 1991), the majority of respondents preferred image based data in their information search phase.

\subsection{Information by Different Media}

Table 1 shows that, TV program (mean=3.96) is the media which respondents can receive the most significant information from that. The second media which the respondents received significant information is advertisement $($ mean $=3.61)$. Website $($ mean $=3.57$, movie $($ mean $=3.35)$, brochure $($ mean $=3.34)$ and magazine $(m e a n=3.29)$ are the other preferred media which tourists use while searching for information. Moreover, poster $($ mean $=3.13)$, journal $(m e a n=3.12)$, newspaper $($ mean= 3.06), billboards $($ mean= 2.99$)$ and flyer $(m e a n=2.92)$ are the less important media that respondents received information from and the information which they received from them are not significant. 


\subsection{Media in Marketing}

Table 2 shows that website (mean=4.16) is the most important media in tourism marketing while the rest are not as much important media in tourism marketing. Magazine (mean=4.09) is the second important media in tourism marketing. Advertisement (mean=4.05), TV program (mean=3.96), brochure (mean=3.89), newspaper $($ mean $=3.86)$, and posters $(m e a n=3.82)$ are the medias which are important in tourism marketing. Billboard $($ mean= 3.77), movie $($ mean $=3.68)$, flyer $(\operatorname{mean}=3.58)$, journal $($ mean= 3.54$)$ and multimedia (compact disk) (mean=3.43), are the lees important media in tourism marketing.

\subsection{Photograph in Travel Decision Making}

The figure 3 shows that the frequency of choosing photographs, as an important factor to choose a destination to visit. 74 respondents refer to photographs as a very important factor while the number of respondents who were unsure are 20 and 6 respondents show their idea by choosing slightly important and the same number is for not at all important; so most of the respondents have an idea that photographs is important or very important in travel decision making.

\subsection{Photographs vs. Reality}

The figure 4 shows that $1 \%$ of respondents mentioned they are strongly disagreed with the statement; 'photographs present the real image of a destination', and 7.8\% was disagreed about it. $34.3 \%$ was neither agreed nor disagreed, $43.3 \%$ were agreed and $13.7 \%$ was strongly agreed that photographs present the real image of a place. Through frequency of respondents' answers, 28 respondents show their disagreement that photographs present the real picture of a destination, 88 of respondents were agreed about it and 70 respondents mentioned that they are neither agreed nor disagreed, while 28 of them were strongly agreed and the rest which were only 2 of them were strongly disagreed. The group who mentioned that they are not neither agreed nor disagreed gives the reason that maybe the picture is not a real picture and they made it by Photoshop or any other computer programs which was not our of study consideration.

\subsection{Photographs in Choice of Destination}

Figure 5 shows that 110 respondents were agreed with photograph as a factor to influence their opinion in order to choose the destination. 58 of them were strongly agreed, 18 respondents were unsure about it while 14 of them were strongly disagreed and just 4 of them were disagreed.

\subsection{Projecting the Character of the Place}

The table 3 shows that majority of respondents refer to natural attraction (mean=4.33) which can be shown by photographs in marketing. Iconic buildings $($ mean=4.05) are the other place character that photographs can represent them better, among others. Photographs are able to show service in the destination (mean=3.93) culture and man-made attractions (mean=3.92) as the other place characters. The rest of place characters are food $(m e a n=3.76)$, people $(m e a n=3.75)$, science and technology $(m e a n=3.50)$, event $(m e a n=3.43)$ and religion $(m e a n=$ 3.10) which photographs are less useful to show them in marketing tourism.

\section{Discussion}

The study shows that in external information search potential tourists look for the necessary information through websites more than other medias. Although using websites as an information source might be different among countries and different people may choose different websites (e.g. official or non official), but the marketers should put their priority on websites as a marketing source and provide a complete information in websites in order to be able to answer most tourists questions. Regarding to respondents preference to receive image based data, marketers should hire expert photographers to snap the proper photographs regarding to their marketing matter. The study shows that photographs are successful to show natural attractions, iconic buildings, service, culture, man-made attraction, food and people. On the other hand it can not successfully show the science and technology, events and religious of a place. Marketers need to come up with new ideas to cover these requirements. Providing short movies for example, can help to show those mentioned characters of a place. The other point is that some people don't acknowledge photos as real pictures of a place since they think they may be fake by using computer soft wares. In this matter marketers can set a link in their websites for pictures were taken by tourists or put the name of photographers to give more credit to their pictures.

This study covers only one small part of the usage of photographs in tourists' information search. Further study can be done in order to find the usefulness of using photographs in the media which tourists search information from. The study can focus on both marketing and non-marketing sources. The comparison will show in which source photographs can be more influential. 


\section{References}

Albers, P. C. and James, W. R. (1988). Travel Photography: A Methodological Approach. Annals of Tourism Research, 15,134-158.

Assael, H. (1987). Consumer Behavior and Marketing Action. Boston: Kent Publishing.

Beatty, S., and Smith, S. (1987). External Search Effort: An Investigation across Several Product Categories. Journal of Consumer Research, 14:83-95.

Bell C. (1914). Art. [Online] Available: http://www.csulb.edu/ jvancamo/361r13.html (2 September 2008).

Benjamin, W. (1979). One-way Street and Other Writings, Verso, London. Cambridge.

Chalfen, R. M. (1987). Snapshot Versions of Life. OH: Bowling Green State University Popular Press.

Chon, K.S. (1987). An assessment of images of Korea as a tourist destination by American tourists. Hotel and Tourism Management Review, Vol. 3, pp. 155-70.

Copeland, M. (1917). Relation of Consumers Buying Habits of Marketing Methods. Harvard Business Review 1:282-289.

Crotts. C. John. (2000). Consumer Decision Making and Prepurchase Information Search. Consumer Behavior in Travel and Tourism, 149-168.

Dann, G. (1995). A socio-linguistic approach to changing tourist imagery. In Butler, R. and Pearce, D. (Eds), Change in Tourism; People, Places, Processes. Routledge, London.

Engel, J., R. Blackwell, and Miniard P. (1995). Consumer behavior. ( $8^{\text {th }}$ ed.) Fort Worth TX: Dryden.

Geary, C. M., and Webb, V.-L. (1998). Delivering Views: Distant Cultures in Early Postcards.

Gernsheim, H. (1991). Creative photography: Aesthetic trends, 1939-1960. Cournier Dover Publication.

Gursoy D and mcCleary KW. (2004). An integrative Model of Tourists Information Search Behavior. Ann> Res,. 31(2): 89-107.

Hawkins, Del I., Best, Roger J., and Coney, Kenneth A. (1995). Consumer Behavior: Implications for Marketing Strategy, Sixth edition. Chicago: Irwin, Inc.

Haywood, M. K. (1990). Visitor-employed photography: An urban visit assessment. Journal of Travel Research, 29(1), 25-29.

Howard, J., and Sheth, J. (1969). The Theory of Buyer Behavior. New York: Wiley.

Human, B. and Warren, J. (1996). Snappers in Brochure land. Tourism Down Under II Conference, University of Otago, New Zealand, December.

Jenkins Olivia. (2003). Photography and travel brochures: the circle of representation. Department of geographical science and planning at university of Queensland, Australia, Vol. 5, pp. 305-328(3).

Larsen, Jonas. (2004). Connecting Tourism and Photography: Corporeal Travel and Imaginative Travel, 2005, Berghahn Journals, Journeys, Vol. 5, No. 2, pp. 19-42.

Löfgren, O. (1985). Wish You Were Here! Holiday Images and Picture Postcards. Ethnologia Scandinavica, 15.

Okazaki, S., and Hirose, M. (2009). Does gender affect media choice in travel information search? On the use of mobile Internet. Tourism Management Tourism Management, Vol. 30, No. 6, pp. 794-804.

Osborne, P.D. (2000). Travelling Light: Photography, Travel and Visual Culture. Manchester and New York: Manchester University Press.

Rodgers, S., and Harris, M. A. (2003). Gender and e-commerce: an exploratory study. Journal of Advertising Research, 43, 322-329.

Schmit, J., and R. Spreng. (1996). A Proposed Model of External Consumer Information Search. Journal of the Academy of Marketing Science, 24:246-256.

Sontag, S. (1977). On Photography. New York: Farrar, Strauss and Giroux.

Sontag, S. (1979). On Photography. Penguin, London.

Taylor, S. J., and R. Bogdan, (1984). Introduction to Qualitative Research Methods: The Search for Meanings. New York: Wilev.

Tonkonow, L. (1995). The cultured tourist. Photography Quarterly, Vol. 16, No. 4, pp. 4-8.

Urry, J. (1990). The Tourist Gaze. Sage, London. 
Table 1. Information by Different Media

\begin{tabular}{|c|c|c|}
\hline & Mean & $\begin{array}{c}\text { Std. } \\
\text { Deviation }\end{array}$ \\
\hline TV Program & 3.93 & 1.043 \\
\hline Advertisement & 3.61 & 1.325 \\
\hline Website & 3.57 & 1.313 \\
\hline Movie & 3.35 & 1.291 \\
\hline Brochure & 3.34 & 1.236 \\
\hline Magazine & 3.29 & 1.128 \\
\hline Poster & 3.13 & 1.197 \\
\hline compact disk & 3.13 & 1.292 \\
\hline Journal & 3.12 & 1.108 \\
\hline Newspaper & 3.06 & 1.238 \\
\hline Billboards & 2.99 & 1.275 \\
\hline Flyer & 2.92 & 1.094 \\
\hline \multicolumn{2}{|c}{}
\end{tabular}

Table 2. Media in Marketing

\begin{tabular}{|c|c|c|}
\hline & Mean & $\begin{array}{c}\text { Std. } \\
\text { Deviation }\end{array}$ \\
\hline Website & 4.16 & 1.067 \\
\hline Magazine & 4.09 & 1.023 \\
\hline Advertisement & 4.05 & .935 \\
\hline TV program & 3.96 & 1.105 \\
\hline Brochure & 3.89 & 1.068 \\
\hline Newspaper & 3.86 & .973 \\
\hline Poster & 3.82 & 1.169 \\
\hline Billboards & 3.77 & 1.199 \\
\hline Movie & 3.68 & 1.288 \\
\hline Flyer & 3.58 & 1.144 \\
\hline Journal & 3.54 & 1.205 \\
\hline compact disk & 3.43 & 1.127 \\
\hline & &
\end{tabular}

Table 3. Projecting the Character of the Place

\begin{tabular}{|c|c|c|}
\hline & Mean & $\begin{array}{c}\text { Std. } \\
\text { Deviation }\end{array}$ \\
\hline Natural Attraction & 4.33 & .955 \\
\hline Iconic Buildings & 4.05 & .914 \\
\hline Services & 3.93 & .891 \\
\hline Culture & 3.92 & .884 \\
\hline Man-made Attraction & 3.92 & .989 \\
\hline Food & 3.76 & .943 \\
\hline People & 3.75 & .938 \\
\hline Sciences and Technology & 3.50 & .842 \\
\hline Events & 3.43 & .926 \\
\hline Religion & 3.10 & .998 \\
\hline
\end{tabular}




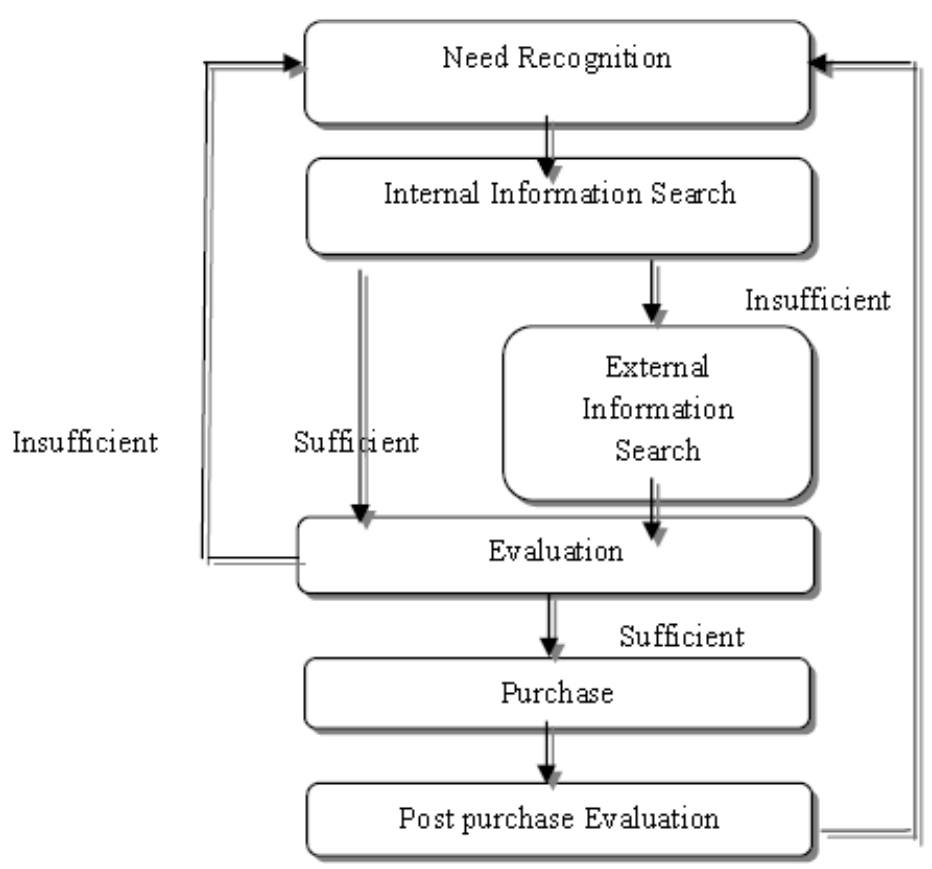

Figure 1. Model of Pre-purchase Information Search

Source: Crotts, (2000, p. 153)

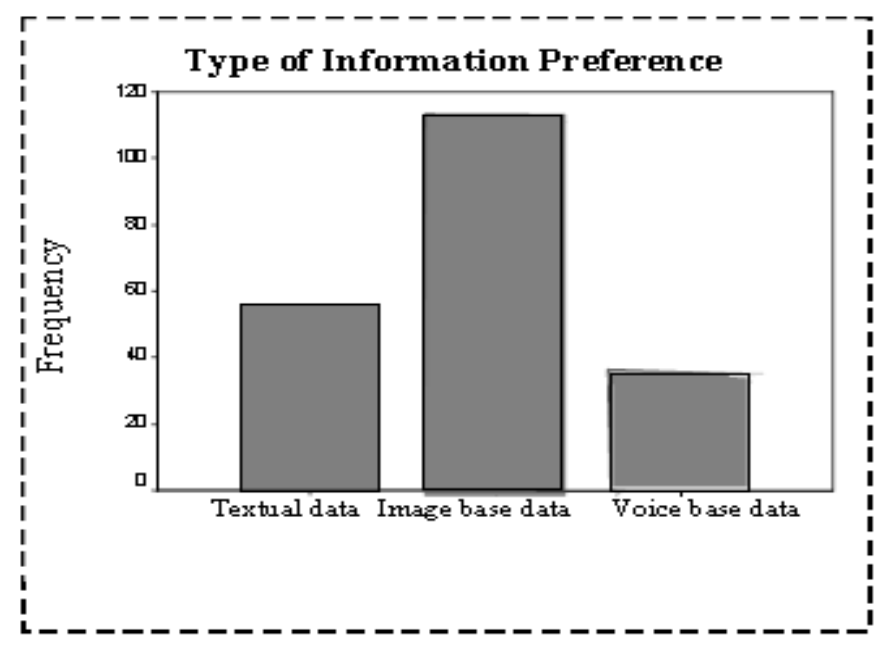

Figure 2. Information preference 


\section{Importance of Photographs}

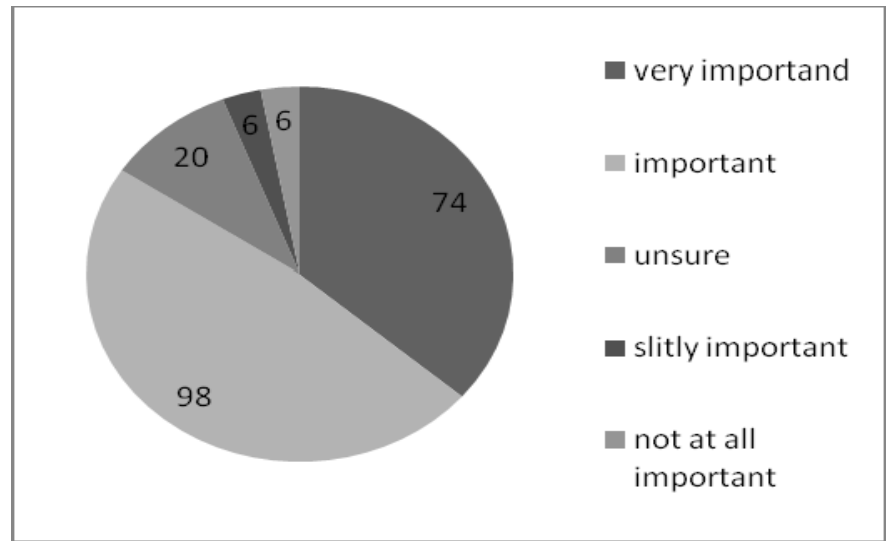

Figure 3. Photographs in Travel Decision Making

Importance of Photographs/Real Picture of a Destination

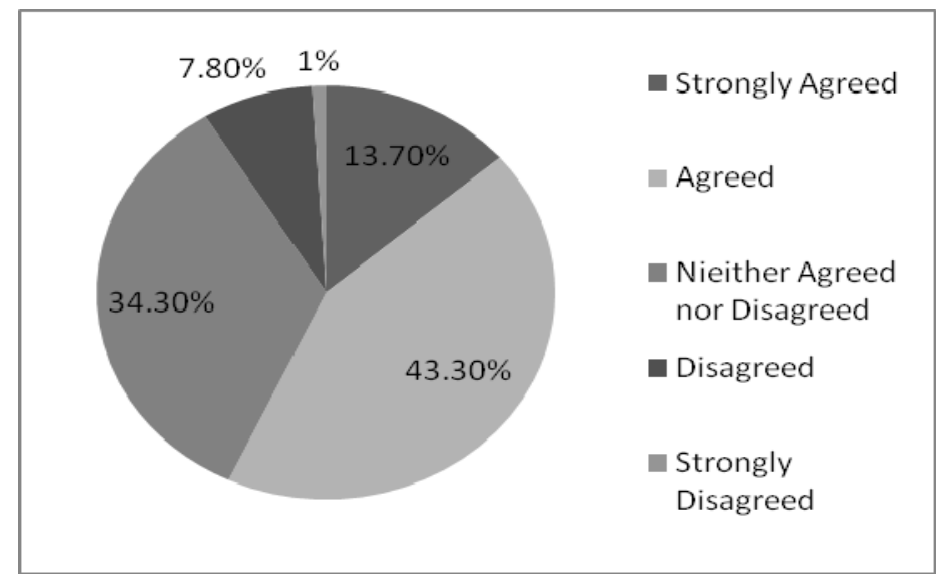

Figure 4. Photographs vs. Reality

\section{Influence of Photographs/Choice of Destination}

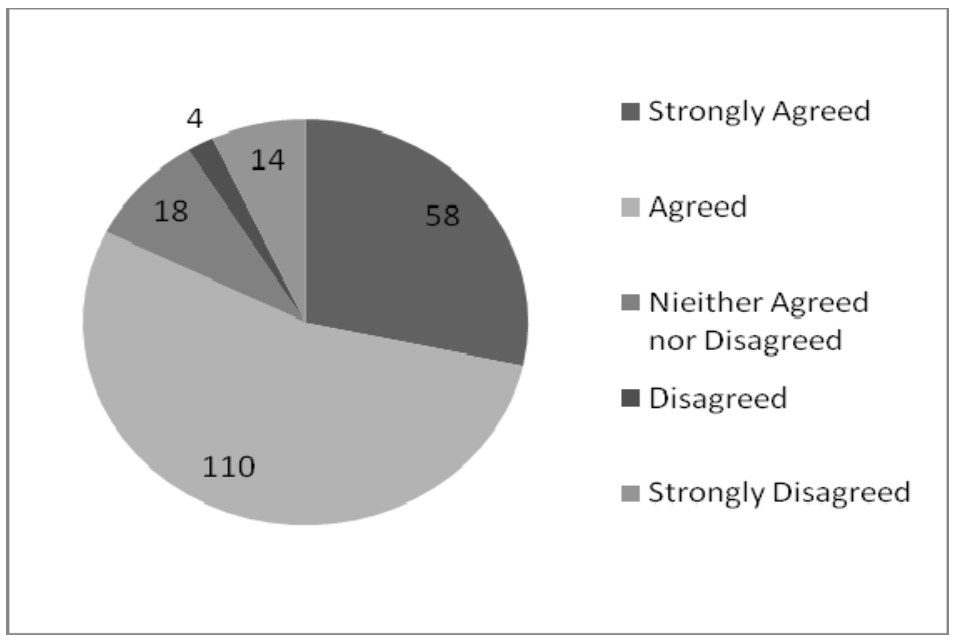

Figure 5. Photography in Choice of Destination 